\title{
Damnatio eternae mortis or medicinalis non mortalis: the ambiguities of excommunication in thirteenth-century England
}

\section{Felicity G. Hill}

Excommunication resulted in complete separation from the Christian community. This basic definition can be accepted without difficulty. To go further, however, is problematic.

Excommunication's precise implications were far from clear. An excommunicate was to be shunned by all other Christians; he or she could not be buried in ecclesiastical ground and was unable to sue in court. Yet excommunication was also a spiritual sanction. A frequently cited canon from Gratian's Decretum defined anathema as 'damnation of eternal death'.

Nevertheless, in 1245, at the first Council of Lyons, Pope Innocent IV emphatically asserted, 'excommunication is medicine not death, discipline not annihilation'. ${ }^{2}$ This decree, known as 'Cum medicinalis', added to an already significant body of canon law intended to ensure that clerics used excommunication justly, and sparingly. In the same period, theologians had reached a consensus that excommunication was not a curse, and did not send a person to hell. Yet excommunication continued to be 'burdened with great ambivalence', as Elisabeth Vodola has observed. ${ }^{3}$ Despite the definition in 'Cum medicinalis' and the assurances of theologians, it was not uncommon throughout the middle ages for both churchmen and laymen to believe that excommunication resulted in 'misfortune in this world and damnation in the next'.

This observation is hardly new. Martin Luther complained about the problem as early as 1518. The most full study of this tension is Alexander Murray’s 1991 John Coffin Memorial Lecture, in which he explores the complexity of the issues at stake. Vodola and R.H. Helmholz

\footnotetext{
${ }^{1}$ Anathema came to be understood as major excommunication. Decretum Gratiani, C.11 q.3. c.41. All canon law references are from the Corpus iuris canonici, ed. Friedburg (2 vols., Leipzig, 1881).

${ }^{2}$ Decrees of the Ecumenical Councils, ed. and trans. Norman P. Tanner (2 vols., London, 1990) i, 291; VI. 5.11.1.

${ }^{3}$ E. Vodola, Excommunication in the Middle Ages (Berkeley, 1986), p. 46.

${ }^{4}$ Alexander Murray, Excommunication and Conscience in the Middle Ages, John Coffin Memorial Lecture (London, 1991), p. 22, reprinted in his Conscience and Authority in the Medieval Church (Oxford, 2015).

${ }^{5}$ Martin Luther, 'Sermo de virtute excommunicationis', in D. Martin Luthers Werke: Briefwechsel I, ed. J.K.F. Knaake et al. (Weimar, 1930), pp. 638-43, cited in Vodola, Excommunication, p. 1.
} 
have likewise carefully noted that excommunication remained linked to cursing long after the thirteenth century. Nevertheless, the years surrounding 1200 have been seen as a turning point. Thus for Vodola, by the early thirteenth century, 'it was evident ... that major excommunication concerned only the punishment that detained a soul in purgatory, not the guilt that consigned it to hell' ${ }^{6}$ Helmholz has described a competition during the twelfth century between two conceptions of excommunication: judicial sanction versus powerful curse. He argues that the former had won a (qualified) victory by the end of the century. ${ }^{7}$ That the first writs ordering recalcitrant excommunicates to be detained by the secular arm date from the beginning of the thirteenth century further indicates a watershed in the development of excommunication around this time. ${ }^{8}$

Developments in canon law and theology were no doubt important, and had significant effects on the use and understanding of the church's most severe sanction. Yet for the majority of people living in thirteenth-century England, it is highly likely that the information they received regarding excommunication encouraged the belief that it was indeed a curse affecting both body and soul. ${ }^{9}$ Definitions of excommunication continued to indicate that it resulted in damnation; miracle stories described the horrible fates of excommunicates; and the ritual denunciation of excommunicates, verbally and symbolically, seemed to condemn such people to hell.

Theological niceties reached the greater proportion of the population only slowly and in highly simplified form. Legal and bureaucratic procedures prevented abuse of excommunication and dimmed the impression that excommunication was a curse, but there was nothing (except conscience) to stop a cleric acting vengefully if his cause was just and he followed procedure. Finally, Donald Logan's assertion that full ceremonial excommunication was 'rare indeed' is

\footnotetext{
${ }^{6}$ Vodola, Excommunication, p. 45.

${ }^{7}$ R. H. Helmholz, 'Excommunication in twelfth century England', Journal of Law and Religion, 11 (1994-95), 23553; R. H. Helmholz, The Spirit of Classical Canon Law (London, 1996), pp. 366-76.

${ }^{8}$ F. D. Logan, Excommunication and the Secular Arm: A Study in Legal Procedure from the Thirteenth to the Sixteenth Century (Toronto, 1968), pp. 17, 22-3.

${ }^{9}$ Though this was by no means confined to England.
} 
highly misleading. ${ }^{10}$ This ceremony would have been familiar to most people living in thirteenthcentury England.

Miracle stories, the importance of ritual excommunication, and contradictions over the sanction within legal sources have by no means gone unnoticed in studies of excommunication. ${ }^{11}$ Yet the focus of the most prominent works on excommunication in this period has been on law. The result here has been a false de-dramatization of the ritual and popular perception of excommunication. The persistent belief that excommunication had serious implications for life and the afterlife was thus not an anomaly, an error, or a misconception based on antiquated or 'folkloric' ideas about excommunication. Rather, it was a belief that the church sought to encourage. Nor was the idea encouraged only for the laity; it was also propagated within the ecclesiastical hierarchy. If such ideas were not in accordance with the church's official stance, evidence for excommunication presented as spiritually damning is far too prevalent for it to be dismissed as an occasional anachronism. Even 'Cum medicinalis' asserted that excommunication was not death, provided it was not treated with contempt, in which case, presumably, it was.

The problem with excommunication was that it was 'quaedam maledictio', as it was phrased in the Supplement to Thomas Aquinas's Summa Theologiae. ${ }^{12}$ Maledictions, or curses, were forbidden in the Bible (Romans 12:14), and were certainly not compatible with New Testament teachings that emphasised love and forgiveness. ${ }^{13}$ The church was thus forced to justify excommunication, and to counter arguments against its use. It was claimed that not only was excommunication acceptable, but that it was in fact necessary, as long as the intent was medicinal and not punitive - excommunication was not a punishment, but a remedy. Moreover,

\footnotetext{
10 'Excommunication' in Dictionary of the Middle Ages, 13 vols. ed. J.R. Strayer et al., (New York, 1982-88), vol. iv.

${ }^{11}$ Vodola, Excommunication, pp. 44-7; Logan, Excommunication, p. 13; Murray, Excommunication, pp. 19-20; Cristian Jaser, 'Ritual excommunication: an “Ars Oblivionalis”?', Memory and Commemoration in Medieval Culture, ed. Elma Brenner, Meredith Cohen, Mary Franklin-Brown (Farnham, 2013), pp. 119-139; Helmholz, 'Excommunication in twelfth century England'.

12 Thomas Aquinas, Summa Theologiae, Bk III-Supplementum, q. 21, a.2, in Opera Omnia iussu Leonis XIII, vol. xii (Rome, 1906).

${ }^{13}$ Murray, Excommunication, pp. 15-24.
} 
theologians moderated the effects of excommunication, insisting that it would not result in bodily affliction while someone was living, nor in damnation after death.

The Dominican writer of the Supplement justified the use of excommunication in a number of ways, in a quaestio asking whether it ought to be used at all. First, excommunication, he argued, could be found in the Bible, in 1 Corinthians 5:5 and Matthew 18:17. More importantly, the purpose of excommunication was to shame the sinner into returning to the bosom of the church, not to separate him from it irreparably. There were two types of curse. In the first, the evil inflicted was the sole intent. This type of curse was forbidden in every way. But the second was when the evil was used for good, medicinal purposes. The medicinal quality of the sanction was thus emphasised: cursing with good intentions was licit and salutary, as when a doctor inflicts pain during surgery in order to cure a man. ${ }^{14}$ Bonaventure used the same medical analogy (an extremely common one). Excommunication is medicine for a rebellious person because it cures the disease of rebellion, just as surgery is medicine for an abscess even though it causes pain. Bonaventure also stated that while an excommunicate was separated from the sacraments and from corporal communication, no one was separated from spiritual communion. ${ }^{15}$ Thus the severity of excommunication, in spiritual terms, was lessened by theologians. ${ }^{16}$ Yet their justification was problematic: the only thing that distinguished a 'good' curse from a 'bad' curse was the intent. This was surely a rather dangerous position. Pronouncing a curse in order to harm the sinner would harm only the one pronouncing it, but there was nothing except conscience to stop him doing so.

Therefore, attempts were made to limit the use of excommunication. Just as theologians stressed the importance of intent, canon law endeavoured to ensure that those able to excommunicate did so with the right motives. This was chiefly done by imposing procedures on

\footnotetext{
${ }^{14}$ Aquinas, Summa Theologiae, Bk III-Supplementum, q. 21, a.2.

${ }^{15}$ Bonaventure, Commentaria in quatuor libros sententiarum magistri Petri Lombardi, in Opera Omnia, vol. IV, ed. P. Bernardini (Quaracchi, 1889), Bk IV. d. 18. p.2 a.1 q.1 (Tome 4, 484-5).

${ }^{16}$ For a fuller discussion of theological developments, see Murray, Excommunication, 15-24. Separation from the Eucharist - which was essential to salvation - was itself a serious matter, however.
} 
clergy using the sanction. Though there had always been such restrictions, legal procedure was increasingly compulsory, and clergy who flouted the requirements were to be punished. The aim was to prevent spontaneous and vengeful 'curses', since these were liable to be unjust or unlawful. The 1215 Lateran Council issued an important decree that warnings, in the presence of witnesses, had to be given before a sentence could be pronounced. ${ }^{17}$ Most crucially, the 1245 Council of Lyons set out the church's official position on excommunication with 'Cum medicinalis', which also reflected the views of theologians. The canon emphasised the spirit with which excommunication ought to be used - for correction and healing. Sentences were to be delivered in writing, with the cause clearly explained, and the person sentenced was to have a copy if he requested one. It was thus impossible to issue a legal sentence without reasonable cause; to do otherwise would result in appeals, and ultimately in sanctions against the cleric who had acted hastily or unjustly. Whilst complaints against those who had acted against the decrees of the ecumenical councils were not uncommon long after their promulgation, these decrees no doubt affected practice.

'Cum medicinalis' was, in Vodola's words, 'the most momentous change of all' in the development of excommunication. ${ }^{18}$ It was duly incorporated into the canon law collection the Liber Sextus as the opening clause on excommunication (VI 5.11.1), and was frequently cited thereafter. Yet despite its fundamental importance for the Catholic Church's stance on excommunication, and its profound influence, it did not eradicate older definitions of excommunication. The medicinal purpose of excommunication expressed in 'Cum medicinalis' was flouted in practice, but it was never contradicted in theory, so far as I am aware. Whilst clerics might issue sentences in the wrong spirit, it was never argued that this was acceptable. Nevertheless, if the medicinal intent of excommunication was always stressed or implied,

\footnotetext{
${ }^{17}$ Decrees of the Ecumenical Councils, i, 255; Constitutiones Concilii quarti Lateranensis una cum Commentariis glossatorum, ed. Antonius García y García, Monumenta Iuris Canonici, Ser. A, vol. 2 (Vatican, 1981).

${ }^{18}$ Vodola, Excommunication, p. 42.
} 
damnatory consequences - contradicting the assertion that excommunication was neither death nor annihilation - were conveyed in legal, narrative, didactic and liturgical sources.

The essential point of 'Cum medicinalis' was that excommunication was a serious matter, and ought thus to be treated with caution and due consideration. It was supposed to deter clerics from issuing sentences unless truly necessary, that is, once it was clear that there was no other means by which the person at fault might be corrected. This was already the intent of a canon from the 845 Council of Meaux, which had nonetheless defined anathema as damnation of eternal death. This canon was included in Gratian's Decretum, and its definition was often used in relation to excommunication (C.11 q.3 c. 41$).{ }^{19}$ Though this definition was at odds with that of Innocent IV, the aim of the canon as a whole was aligned with that of its successor. This clause ordered that anathema be used only for mortal sins. Like 'Cum medicinalis', it was supposed to curb use of the sanction. It differed only in its means of persuasion against the use of such sentences. Long after 1245, prelates continued to impress upon their subordinates that excommunication was so severe that it had to be treated carefully and in accordance with law. This might be done by stating that it did endanger the salvation of those sentenced, and if used unfairly, of the cleric pronouncing the sentence.

English legislation, like the universal canon law, tried to ensure that excommunication was used properly. Yet 'Cum medicinalis', however great its significance more generally, was given no particular prominence. ${ }^{20}$ Many statutes provided no definition of excommunication, but we find John Pecham, archbishop of Canterbury (1279-90), in provincial statutes, observing that excommunications incurred through ignorance plunged people into a 'pit of danger'; excommunication 'struck down' wicked men, and those who absolved excommunicates when

\footnotetext{
${ }^{19}$ Anathema and major excommunication were often treated synonymously. Corpus iuris canonici, i, col. 1239.

20 'Cum medicinalis' is referenced in the Statutes of Wells, Councils and Synods II: 1205-1313, ed. F. M. Powicke and C. R. Cheney (2 vols., Oxford, 1964), i, p. 621; the Statutes of London I, ibid., pp. 631-2; the Statutes of London II, ibid. i, pp. 650-1; the Statutes of Exeter II, ibid., ii, pp. 1040-1.
} 
they had no legal right to do so were bringing back to life souls that did not live. ${ }^{21}$ Oliver Sutton, bishop of Lincoln (1280-99), in a mandate ordering promulgation of automatic sentences, referred to the danger of being separated from God and from the faithful, and of being 'released to the possession of hell'. He encouraged those who had fallen into such sentences to repent and in future to abstain from excesses and 'the bonds of eternal damnation' ${ }^{22}$ Rather than stressing the importance of medicinal intent, both prelates emphasised the serious consequences for souls if the law was not followed, not only by clerics with a duty of care, but by guilty parties.

The point is best demonstrated in a clause contained in the diocesan statutes of Exeter, promulgated in 1289. Given the rubric 'De excommunicationum sententiis cum deliberatione promulgandis', this brings together various canons relating to excommunication. It particularly emphasises that the sanction was a serious matter and needed to be handled accordingly. The clause begins by advising that those who have the power of binding and loosing through the keys of St. Peter should be aware of how great that power is, since they have this honour through Christ. Next, it is explained that, since excommunication is damnation of eternal death, it should be imposed only for mortal sins, and only on those who cannot otherwise be corrected (C.11 q.3 c.41, as above). Provident deliberation and maturity are needed, since an unjust excommunication injures he who issues it rather than he who is sentenced (C.11 q.3 c.87). Next, clerics are warned, in accordance with Lateran IV (c. 47), that sentences be issued only with reasonable cause, and only after three warnings, made in the presence of witnesses (X 5.39.48). The cause of a sentence should be expressly written down and a copy be given to the excommunicate within one month if requested (VI 5.11.1), this being the substance of ' $\mathrm{Cum}$ medicinalis' but without its opening definition. The rest of the clause concerns the social consequences of excommunication, and the ways in which the community was made aware of excommunicates: parish priests were to publicise their names and the causes of their sentences,

${ }^{21}$ Councils and Synods II, ii, pp. 898-9.

${ }^{22}$ The Rolls and Register of Bishop Oliver Sutton, 1280-1299, ed. R. M. T. Hill, 8 vols. (Lincoln Record Society, 1948-75), iv, p. 35. vi, pp. 24-7. 
using candles and bells, to ensure that nobody communicate with them through ignorance of their excommunicate status. ${ }^{23}$

This Exeter constitution thus uses a definition of excommunication that was against both 'Cum medicinalis' and the tenets of theologians. Yet its purpose was precisely in line with both. It sought to counter abuse of excommunication. The only real difference between the Lyons and Exeter decrees is the argument used. 'Cum medicinalis' emphasised what excommunication was supposed to be used for - not revenge or punishment but only to correct those who had strayed while the Exeter clause stressed that appropriate care was necessary because of the serious consequences of any sentence. It is possible that the Exeter canon used the earlier definition simply because it was a compilation, in chronological order, of various canons. Its definition, derived from Gratian, came from a source earlier than Lyons (1245), and rendered a second definition obsolete. Yet it might also have been a calculated strategy. One aim of the clause was to reduce use of the sanction, which, it has been argued (with good reason), was overused. ${ }^{24}$ Underlining that it sent people to hell was perhaps a better means of persuading clergy to 'use with care' than stressing that excommunication was medicine not death. Whether or not this was the reason, it is certain that in legal texts, primarily intended for clergy, there was a degree of ambiguity about what excommunication meant for the afterlife. Perhaps the idea that excommunication had hellish consequences was simply too ingrained to be dismissed, but the idea that it resulted in damnation was certainly not expunged.

Miracle stories were another means by which such ideas continued to be communicated to medieval society. Not only did they describe how excommunicates suffered after death, but also how they were tormented while living. Such miracle stories - whether or not they were believed - were a crucial means through which the laity, in particular, were taught about excommunication. Such stories were included in saints' lives and chronicles, and incorporated

\footnotetext{
${ }^{23}$ Councils and Synods II, ii, pp. 1040-1, cf. The Statutes of Wells, ibid., i, p. 621.

${ }^{24}$ R. M. T. Hill, 'The theory and practice of excommunication in Medieval England', History, 42 (1957), 1-11.
} 
into lists of exempla which preachers could draw upon to liven up their sermons. It is therefore not unreasonable to conclude that they reached a wide audience. ${ }^{25}$

Numerous excommunication miracles survive, supposed to demonstrate the various supernatural consequences of excommunication. Thematically organised sermon exempla collections might include a section on the sanction. In some such collections, the tales were preceded by a definition of excommunication. Thus the Speculum laicorum, composed in England some time during the reign of Edward I, described excommunication as a spiritual sword that divided men from the unity of the church, just as a limb from a body or a branch from a tree-trunk. An excommunicate was to have the burial of an ass (Jeremiah 22:19): as the skin of a dead ass is used by men, its body eaten by dogs, and its intestines played with by ravens, so an excommunicate's possessions are given to his heirs, his body to vermin, and his soul to demons. ${ }^{26}$ The collection of the French preacher Stephen of Bourbon (which, it should be noted, probably did not circulate in England in this period) frequently introduces individual tales with a definition matching whatever aspect of excommunication the subsequent narrative was intended to illustrate. Thus 'Excommunication is the mouse-trap or fishing-net of the devil'; 'it corrupts and blackens the soul with malediction, as a diabolic stain'; 'Anathema hands over to Satan'; 'it kills with sudden and bad and unexpected death', and most emphatically: 'Excommunicates are eternally burned in the infernal fire, and are devoured and dissipated by demons' ${ }^{27}$ The tales do not disappoint in providing apt examples.

Although some stories are unique to particular collections, many can be found in several places, adapted to feature different protagonists or geographical locations, while remaining

\footnotetext{
${ }^{25}$ Friars' Tales: Thirteenth-century exempla from the British Isles, ed. and trans. David Jones (Manchester, 2011), pp. 14, 24-6.

${ }^{26}$ Speculum laicorum, edition d'une collection d'exempla, composée en Angleterre à la fin du XIII siècle, ed. J. Th. Welter, Thesaurus Exemplorum, fasc. 5 (Paris, 1914), p. 56.

${ }^{27}$ Anecdotes Historiques, Légendes et Apologues: Tirés du Recueil inédit d'Étienne de Bourbon, ed. A. Lecoy de la Marche (Paris, 1887), \#307, 308, 309, 313, 314. A new edition is being prepared for the Corpus Christianorum Series Latina: Tractatus de Diversis Materiis Predicabilibus, ed. Jacques Berlioz and Jean-Luc Eichenbach (Turnhout, 2002-). The relevant sections of the text have not yet been printed in this edition.
} 
essentially the same. For instance one particularly common miracle relates how a sceptic is convinced of the powers of excommunication when a cleric excommunicates some bread, which immediately turns black. Upon its absolution, it reverts to its original white form, thus also demonstrating the virtue of absolution. One version of this story has Thomas Becket as the anathematizer, another the heretic Count Raymond of Toulouse as the sceptic. Many others simply involve local figures, named or unnamed: the miracle was adjusted to have the greatest relevance to its audience (though the northern Lanercost chronicle sets it in Lombardy). ${ }^{28}$ Alongside the bread miracle may be placed numerous stories in which animals and lands are excommunicated or anathematized. In the Liber exemplorum, a thirteenth-century British collection created for friars, the value of such miracles is explained by a quotation from Gerald of Wales: 'For if a curse has such great power over ... snakes and tiny creatures, whose animal nature excuses them from sin, should not legitimately imposed excommunication ... be greatly feared by men endowed with reason who knowingly commit sins from which they cannot be excused?'29

Exempla focused on excommunicated people publicised the idea that excommunication caused death, as well as the belief that eternal damnation awaited those who died under a sentence. The Speculum laicorum narrates a miracle found in the life of St Eligius (d. 660), in which an excommunicate is suddenly struck down by death. This is linked with the death of Sapphira in Acts 5, who fell dead at the feet of St Peter. ${ }^{30}$ She is described in the Speculum (but not in Eligius's Life) as having been handed over to Satan. ${ }^{31}$ Another tale, set in the reign of Henry III, describes how a matron walking through a graveyard heard moaning coming from a

\footnotetext{
${ }^{28}$ For some (undoubtedly not all) occurrences of this miracle, see: F.C. Tubach, Index exemplorum: A Handbook of Medieval Religious Tales (Helsinki, 1981), \#754; Catalogue of Romances in the Department of Manuscripts in the British Museum, ed. J.A. Herbert, vol. 3 (London, 1910), pp. 446, 615, 719; Anecdotes Historiques, \#308; Chronicon de Lanercost, ed. J. Stevenson (Maitland Club, 1839), pp. 132-3.

${ }^{29}$ Friars' Tales, p. 108; Gerald of Wales, Gemma Ecclesiastica, in Giraldi Cambrensis Opera, ii, ed. J. S. Brewer (London, 1862), p. 161.

${ }^{30}$ Sapphira and her husband Ananias were also frequently cited in excommunication rituals.

${ }^{31}$ Speculum laicorum, \#277. This tale is one of those not edited by Welter (his edition is selective); British Library, Additional MS 11284, f. 36v. 'Handed over to Satan' is a reference to 1 Corinthians 5:5, for which see below.
} 
grave. When asked the cause of the moaning, the spirit replied that an excommunicate was due to be buried with it in the same grave later that day, 'and thus my bones will have no peace until Judgement Day'. The reader (or listener) is told to consider 'how the souls of excommunicates are disturbed in hell' ${ }^{32}$ Other stories reflected a common trope that bodies of excommunicates did not decay. The Speculum describes the grave of an excommunicate being found filled with foetid and boiling water and containing a bloody corpse (which dissolved into dust when absolved): 'Therefore everyone should pay attention to how his soul boiled in hell, when his body had so boiled in the grave'. ${ }^{33}$ Yet that people might scoff at the purported consequences of excommunication was accepted. A particularly amusing story included by Stephen of Bourbon addressed this issue. A usurer had remained excommunicated for a long time, and boasted that, despite his sentence, he had a stout belly and fat cheeks: 'See how the maledictions of priests have desiccated me!' To which the narrator's response is 'Poor man, little did he know that God had fattened him up like a pig to suffer eternal death, and that he would certainly and shortly suffer sudden death. ${ }^{34}$

One story, apparently composed in England in the second half of the thirteenth century, can be taken to represent attitudes to excommunication in thirteenth-century England and is worth describing in detail. It was later abbreviated by John Bromyard, and turned into a Middle English poem by John Lydgate (here the original Latin text is used), and thus had significant transmission in the later middle ages. ${ }^{35}$ Despite the date of its composition, the lengthy narrative is set in Oxfordshire, in the time of St Augustine of Canterbury, shortly after the Anglo-Saxon conversion. The purpose of the story was first to convince people to pay their tithes, and second to impress upon them the power of excommunication.

\footnotetext{
32 Speculum laicorum, \#280.

${ }^{33}$ Speculum laicorum, \#281. See also Index exemplorum, \#1924.

${ }^{34}$ Anecdotes Historiques, \#55.

${ }^{35}$ Nine MSS survive containing the original text. These have been collated by E. Gordon Whately, who discusses the story's later history in 'John Lydgate's Saint Austin at Compton: The Poem and its Sources', in Anglo-Latin and its Heritage: Essays in Honour of A.G. Rigg on his 64 ${ }^{\text {th }}$ Birthday, ed. Siân Achard and Gernot R. Wieland (Turnhout, 2001), pp. 191-227.
} 
In Augustine's own day, a village priest had failed to convince his local lord to pay his tithes, and had threatened him with excommunication. Informed of this, Augustine summons the knight, and quizzes him about the matter, informing him that a tenth of everything belongs to God. The knight insists that it is he who had cultivated the land, and it therefore belongs to him and not to God. He is duly excommunicated by the saint. Augustine then goes to church to celebrate mass, and orders excommunicates to leave before this takes place: a body is seen to rise from its tomb and leave the church. After mass, the 'pious shepherd' and 'terrified sheep' approach the 'foul and deformed cadaver' in the cemetery, who explains that angels had expelled him when Augustine had ordered 'stinking flesh [i.e. excommunicates] to be thrown out of the church'. The corpse was a Briton who had been excommunicated (before the pagan AngloSaxon invasion) because he never paid his tithes, and who had died under this sentence. He explains that thus he had hurled his soul into 'the infernal confines to be tortured continually in the fires'. Augustine then performs a miracle, resurrecting the British priest who had excommunicated the man, and the priest confirms the cause of the sentence, insisting that he had reason, since the man was always a rebel and a retainer of tithes. He too describes how the man had been 'enclosed in the dark prison' and had 'sustained hellish punishments'. The resurrected priest then imposes penance on the excommunicated corpse, who, once absolved, crumbles into dust and ash. The priest firmly declines Augustine's invitation to give up the 'delights of eternal life', which he had been enjoying, to return to 'the laborious suffering' of temporal life to preach the gospel. Before the story ends with the lord of Augustine's own time seeing the error of his ways, the narrator interjects to quash any doubts amongst his readership that Augustine could have performed such a miracle, and observes that 'there is no doubt that the stiff necks of the English were never accustomed to be subjected to the yoke of Christ except through great miracles'. 
The tale makes clear that those who die obstinately excommunicate will burn in hellish, or at least in purgatorial, fires. It is not difficult to imagine that the story's invention was prompted by the reluctance of certain thirteenth-century parishioners to pay their tithes, and the need for miracles to convince people is explicitly stated. It is clear why such stories continued to be so popular with churchmen throughout the middle ages, yet they ran completely contrary to the arguments of the theologians. Not only did they describe damnation as the consequence of excommunication, but they claimed that the bodies and souls of excommunicates were given to the devil or demons. This idea originated in 1 Corinthians 5:5, in which fornicators are handed over to Satan for 'destruction of the flesh', so that their spirits might be saved. Since this was one of the Biblical justifications for excommunication, theologians were forced to explain the verse, and to counter the objection that no one should be given to the hands of his enemies unless 'omnino desperatus'. ${ }^{36}$ Since no one should be despaired of in life, surely no one should be subjected to excommunication? Franciscans and Dominicans insisted that the condemnation was not as bad as it seemed. It meant, they wrote, that an excommunicate was merely exposed to Satan, in that protection from him was withdrawn. It did not mean that Satan was being ordered to afflict them. Nor was this 'for damnation', but rather for correction. They also reached the conclusion that excommunicates were no longer afflicted in their bodies. In the 'primitive' church, it was necessary to entice ('invitare') men to faith through visible signs, and thus, just as the gift of the Holy Spirit was manifest, so also excommunication was made conspicuous with corporal vexation by the devil. By contrast, in their own time, they observed, excommunicates were still exposed to the devil but were not visibly harassed. Alexander of Hales's explanation for this was that the devil himself chose not to vex corporally, since in the primitive church he had learnt that this caused many to return to the church, and to fear excommunication. Because this way he lost souls, he refrained from using his power and left sinners to their disobedience

\footnotetext{
${ }^{36}$ The following is based on Aquinas, Summa Theologiae, Bk III-Supplementum, q. 21, a.2, but Bonaventure, Commentaria, Bk IV. d. 18. p.2 a.1 q.1 makes the same argument.
} 
and separation from the church. ${ }^{37}$ It would have been obvious that most excommunicates did not suffer visible signs of their plight, and it makes some sense that theologians should make an effort to explain this. Nevertheless, it is evident that many churchmen tried to convince the laity that such miracles did indeed still occur (the majority are set in the recent past), and that excommunicates were visibly harassed by the devil or demons. Meanwhile, the verse from Corinthians was inextricably linked with excommunication (for instance it was cited twice by Gratian $^{38}$ ), but without the mollifying glosses of theologians, it stated simply that excommunicates were handed over to the devil for their flesh to be destroyed.

Excommunication miracles usually presented excommunication in a way that theologians might well have considered unjustifiable. The results of these sentences too closely resemble the effects of curses. Yet the clerics in most of these stories (where the cause as well as the effects are described) did not issue sentences with the intention of cursing, as theologians held they must not. The excommunicates were supposed to be convinced to return to the church; it was their own refusal to do so that resulted in their terrible comeuppance. The intent might thus still be described as medicinal, even if the ultimate result was not. It is worth noting that the Corinthians chapter at the heart of such ideas also reflects this sentiment: the flesh was handed over to Satan to be destroyed only so that the spirit might be saved.

One final miraculous excommunication - from a rather different source - was issued as a curse, without any hint of medicinal intent. The story, told by Matthew Paris in his Chronica Majora, provides a link between excommunication miracle tales and thirteenth-century practice. Paris described the excommunication of William Marshal, the great knight, in order to provide an explanation for subsequent events. The story was included in Paris's chronicle under the year

\footnotetext{
${ }^{37}$ Alexander of Hales, Summa Theologica, vol. IV(1), ed. P. Pacifici M. Perantoni (Quaracchi, 1948), Bk III, pp. $159-61$.

${ }^{38}$ C. 11 q. 3 c. 21 ; C. 11 q.3 c. 32.
} 
1245, when the last of the Marshal's five sons, none of whom had produced an heir, died. The events, however, take place in 1219 . True or not, the story is illustrative. ${ }^{39}$

Paris attributed the death of the Marshal's five childless sons to the excommunication of their father. While in Ireland, the Marshal had apparently seized two manors belonging to the bishop of Ferns. ${ }^{40}$ William refused to return the manors or to heed the bishop's warnings, arguing that as he had acquired them through war, his claim to them was legitimate. As a result, he was excommunicated, 'non immerito'. The Marshal, having never repented nor returned the manors, died under this sentence, and was buried at the New Temple in London. Upon hearing of his death, Bishop Ailbe of Ferns travelled to England and informed the young king Henry III that his former regent had died excommunicated, and asked that Henry arrange the return of his property so that he might absolve the earl. Henry, 'contristatus' at the news, asked the bishop to absolve the earl and promised that he would personally make satisfaction. Speaking to the tomb as if it to a living person, the bishop absolved the earl:

O William, who lies here buried, entangled in the chains of excommunication, if those things which you injuriously stole from my church are restored by the king, or by your heir ... with competent satisfaction, I absolve you; but otherwise I confirm that sentence, so that always bound by your sins you remain condemned in hell.

The king was angry at the bishop's 'immoderate vigour', but Ailbe only replied that he should not be surprised: he had been despoiled of his church's greatest assets. Despite the king's persuasions, the Marshal's sons subsequently refused to return the manors, the eldest saying that he held them by right, because his father had acquired them through war. He said that if the 'old and delirious' bishop pronounced an unjust sentence, 'let his curse be turned on his head', reflecting the idea that an unjust sentence only hurts the one uttering it. The young king (being

\footnotetext{
${ }^{39}$ Matthew Paris, Chronica Majora, ed. H. R. Luard, RS (7 vols., 1872-83), iv, pp. 492-5. David Crouch, William Marshal: Knighthood, War and Chivalry, 1147-1219 (London, 2002), p. 114.

${ }^{40}$ For the background to this dispute, and references, see M. T. Flanagan, 'Ó Máelmuaid, Ailbe [Albinus O'Molloy] (d. 1223)', Oxford Dictionary of National Biography (Oxford, 2004).
} 
only about eleven years old at the time and still 'sub tutore') was unable to do anything further, and the bishop's angry response is remarkable:

What I said, I said; and what I wrote, I wrote indelibly. For the sentence stands, a punishment is inflicted upon the malefactors by the Lord, and the curse which is written in the Psalms is imposed onerously on Earl William, of whom I complain. His name will be destroyed in one generation (Ps. 108:13); and his sons will have no share in that blessing of the Lord, Increase and multiply (Gen. 1:28); and some of them will die with a lamentable death, and their inheritance will be scattered.

These things the king would see while still in the prime of his life. The bishop's words, which left the Marshal bound by anathema, Paris explains, were spoken 'in cordis amaritudine'. Moreover, they all came to pass, with Paris treating the speech as a prophecy. Further proof of the earl's cursed state was revealed in 1240, when the New Temple was rededicated, and his body was found intact, but putrid.

Matthew Paris's account of William Marshal's excommunication is important for a number of reasons. Not only does he portray the bishop issuing a curse, but this was believed, by some at least, to have been effective. Its consequences were certainly more severe than was believed acceptable to theologians. Most importantly, the bishop violated the fundamental rule that excommunication must not be used with the intention to curse. Paris's assertion that he acted 'in bitterness of heart', hardly suggests medicinal intentions, not least because the Marshal was already dead. Yet if in spirit the bishop flouted accepted doctrine, his actions in no way contravened canon law. The details of Paris's account should perhaps be doubted, but the way the chronicler presented the narrative makes clear that he believed the bishop was acting justly and in accordance with proper procedures. Writing in 1245, after he had included the canons of the Council of Lyons in his chronicle, Paris was certainly aware of the church's official stance on excommunication. It may be that this is why he took such pains to emphasise that the sentence was fair. First, he noted that the Marshal had acted violently and injuriously, but responded impudently to the bishop's frequent admonitions, contumaciously retaining the manors. For this 
he was sentenced, 'non immerito'. 'Contempnens' this sentence, he piled injuries upon injuries.

After his death the bishop again told Henry that he had pronounced the sentence 'non immerito'. Moreover, in the second speech the bishop implied that his sentence had also been recorded in writing, indicating at least some kind of legal procedure. The most crucial things here are the bishop's warnings before any sentence was pronounced, and the assertion that the Marshal was behaving 'contumaciter' - the two most fundamental prerequisites for a valid sentence of excommunication. Phrases such as 'piling injury upon injury' can also be found in other sources before a sentence was 'aggravated' (for instance by interdicting lands). Paris thus made use of legal terms associated with excommunication, yet the bishop's spirit and the consequences of his actions are a long way from the 'judicial sanction' of excommunication presented by historians such as R.H. Helmholz.

However many restrictions canon law tried to impose on the use of excommunication, provided procedure was followed, a cleric could act with vengeful intent. Such procedures made it more difficult for a cleric to sentence someone without reasonable cause or to sentence someone without warning (though many appeals indicate that both 'faults' continued to arise on a frequent basis $^{41}$ ), but they did not preclude use of excommunication as a curse. Despite acknowledging that black and white distinctions cannot be drawn, Helmholz's division between 'ex parte anathema' and 'judicial sentence' remains too absolute. The bishop of Ferns' sentence might be aptly described as a 'judicial anathema', as too might other sentences pronounced in thirteenth-century England. Research by Sarah Hamilton and Elaine Treharne has convincingly shown that judicial process was expected far earlier than Helmholz allows, and that he has thus over-emphasised twelfth-century developments. ${ }^{42}$ Though he notes that 'ex parte

\footnotetext{
${ }^{41}$ The phrase used in such complaints is 'non monitos, non confessos, non convictos, absque causa rationabili, et contra statuta concilii generalis', or similar.

${ }^{42}$ S. Hamilton, 'Remedies for "Great Transgressions": Penance and Excommunication in Late Anglo-Saxon England', in Pastoral Care in Late Anglo-Saxon England, ed. F. Tinti, Anglo-Saxon Studies, 6 (Woodbridge, 2005), pp. 83-105; S. Hamilton, 'Absoluimus uos uice beati petri apostolorum principis: episcopal authority and the reconciliation of excommunicants in England and Francia c.900-c.1150', in Frankland: The Franks and the World
} 
excommunications' occurred in the later middle ages, he claims that these, while important to note, were 'outliers', and not representative of the system. Such uses of excommunication might always have been outliers. He partially builds his case around events described in the Life of St Hugh of Lincoln, in which the saint's excommunications - delivered without judicial process killed those sentenced. In fact, even within this text, these examples are 'outliers': the majority of the excommunications pronounced by Hugh were in fact either preceded by warnings and contumacy on the part of the sinners, or in some other way explicitly declared to be fair (the judicial process is not always described, but the point of the story is the miracle not the legal procedure).$^{43}$ It might be added that Helmholz makes the case that the earlier 'powerful curse' was 'dependent for its efficacy upon the spiritual power of the person who issued it, as well as upon the justice of his cause' ${ }^{44}$ Regardless of the presence or absence of legal procedure, the number of clerics with a sufficiently saintly reputation can surely not have been high enough, at any time, for the efficacy of the sanction to be dependent on sanctity alone. Rather, fear of sentences was engineered through a ceremonial ritual designed to scare people, without need for particular personal charisma (though this might help). The anathema was made terrifying through a solemn setting, candles, bells, Biblical quotations and explicit condemnations to hell.

The liturgical ritual of excommunication was the final means by which people were informed about the dangers of excommunication. This is true for the thirteenth century as well as the earlier (and later) middle ages. Donald Logan's assertion in the Dictionary of the Middle Ages that sentences were pronounced in courts, with a simple 'I excommunicate you', and not with the solemn ceremony, is technically correct. It is nevertheless highly misleading. The original pronouncement of a sentence on a named individual was indeed done in this way, but it

of the Early Middle Ages, ed. P. Fouracre and D. Ganz (Manchester 2008), pp. 209-41; E. M. Treharne, 'A unique Old English formula for excommunication from Cambridge, Corpus Christi College 303', Anglo-Saxon England, 24 (1995), 185-211.

${ }^{43}$ The Life of St Hugh of Lincoln, ed. and trans. D.L. Douie and D.H. Farmer, 2 vols. (Oxford, 1961-85), i, pp. 2021, ii, pp. 20-33, 100, 114-16, 157.

${ }^{44}$ Helmholz, 'Excommunication in twelfth century England', pp. 237-8. 
was also required that excommunicates subsequently be denounced in local churches, to ensure that knowledge of their state reached everyone. This was done with candles and bells, much like an anathema. Moreover, general sentences were frequently pronounced in this way, and were a significant part of English thirteenth-century life: every parish priest was to pronounce them four times a year. When a crime covered by an automatic sentence was committed but the perpetrator unknown, general excommunications would be ritually pronounced against whoever had committed the offense while investigations were on-going. Thus, to most parishioners in the thirteenth century the excommunication ceremony would have been a regular and familiar spectacle.

That excommunication ceremonies of some kind took place on a frequent basis throughout England is indisputable. It is less clear, however, precisely what they involved. The ceremony was so common that mandates and legislation did not specify anything more than that it should be conducted in the usual way - with bells ringing and candles burning and extinguished. The form of excommunication in Gratian is that 'Twelve priests ought to stand around the bishop, and hold burning candles in their hands, which in the conclusion of the anathema or excommunication they should throw to the ground and tread on with their feet' ${ }^{45}$ As the gesture was performed, some version of the phrase 'thus his soul is extinguished in hell' was uttered. Variations of this phrase could be more elaborate, for instance one formula from a thirteenth or early fourteenth-century manuscript has 'And thus these lights are extinguished, so they let their souls remain in hell with the devil and his angels' ${ }^{46}$ According to Matthew Paris, during the Magna Carta excommunication in 1237, once the candles were thrown down, the smoke and smell generated caused offence to those nearby by getting in their eyes and going up their noses, during which Archbishop Edmund of Abingdon said, 'thus let the condemned souls be extinguished, smoke and stink', and at the 1253 Magna Carta excommunication ceremony

\footnotetext{
${ }^{45}$ C. 11 q. 3 c. 106.

${ }^{46}$ London, British Library, Additional MS 15236, f. 25r.
} 
Archbishop Boniface of Savoy declared 'thus let those who attack this sentence be extinguished and stink in hell', at which point bells were rung. ${ }^{47}$ The final words of an excommunication, 'fiat fiat, amen amen', were then proclaimed by the whole congregation.

This was the essential ceremony of excommunication. The extinguishing of candles gesturally and orally condemned a soul to hell, in a manner that resembled cursing. The full contingent of twelve priests was, however, clearly impractical for every excommunication and denunciation. A mandate ordering denunciations in 1293, for example, stated that it should be done with the full twelve priests assisting at least once, implying that on other occasions (every Sunday and feast day, as was standard) a lesser ceremony could take place. ${ }^{48}$ Within the basic structure, there was certainly room for variation: pontificals in the Romano-German tradition contain five rituals, of varying length and severity, from which the most appropriate could be chosen. ${ }^{49}$ Unfortunately, excommunication forms definitely in use in England during this period are hard to find, largely due to the lack of surviving pontificals. Even so, similarities between earlier rites and later Latin and Middle English texts allow an argument for continuity. Some denunciations were probably fairly quick and perfunctory, perhaps resembling the 'Excommunicatio brevis' from the Romano-Germanic pontifical, or the form of excommunication (more correctly, of denouncing someone excommunicated) contained in the episcopal register of John le Romeyn, archbishop of York (1286-96).${ }^{50}$ By contrast, there are hints that elements of the more severe anathemas from previous centuries continued to be used. The excommunication of William Marshal, though not a ritual ceremony, made use of Psalm 108, the biblical text most associated with this ceremony. ${ }^{51}$ In 1296, the Lanercost chronicle

\footnotetext{
${ }^{47}$ Matthew Paris, Chronica Majora, v, pp. 361, 377.

${ }^{48}$ Register of Oliver Sutton, iv, pp. 70-2.

${ }^{49}$ Le Pontifical romano-germanique du dixième siècle, 3 vols., Studi e Testi 226, 227, 269 (Vatican, 1963-72), i, pp. 308-17.

${ }^{50}$ Le Pontifical romano-germanique, p. 314; The Register of John le Romeyn, lord archbishop of York, 1286-1296, ed. William Brown, 2 vols. (Surtees Society 123 and 128) (1913-17), i, p. 53.

${ }^{51}$ See Lester K. Little, Benedictine Maledictions: Liturgical cursing in Romanesque France (London, 1993), pp. 63-

7; Cristian Jaser, Ecclesia maledicens: Rituelle und zeremonielle Exkommunikationsformen im Mittelalter
} 
reported that the Scots excommunicated the king of England and the English, and recited Psalm $108 .^{52}$

An excommunication might contain long litanies of maledictions cursing particular body parts, or summarise 'from the top of the head to the souls of the feet', and condemn the excommunicate at all times and in all places: 'let him be cursed while waking, sleeping, sitting, standing, walking...'. There is no direct evidence that such clauses were used in thirteenthcentury England, yet the similarities between earlier rites and those recorded in England in the fourteenth and fifteenth centuries - in both Latin and Middle English - renders it plausible that they were in use.$^{53}$ Excommunication rites often ended by condemning the excommunicates along with various Biblical villains, such as Judas, Caiaphas, Pilate, Ananias and Sapphira and particularly Dathan and Abiron. For this there is some (limited) evidence that such phrases remained in use. Thus a sentence recorded in the bishop of Lincoln's register pronounced that the guilty parties were to receive their lots with Cain the fratricide, and Dathan and Abiron, who were swallowed alive for their crimes. ${ }^{54}$ While in practice it is difficult to distinguish between major excommunication and anathema, it is worth noting that the pontifical of William Durandus (c. 1292-4) refers to minor excommunication, major excommunication, and anathema. Only the latter involved a solemn ritual. ${ }^{55}$ It is thus likely that the common experience of excommunication was not overly dramatic - though denunciations using candles were certainly a

(Tübingen, 2013), pp. 178-85; Roger E. Reynolds, 'Rites of separation and reconciliation in the early middle ages', in Segni e riti nella chiesa altomedievale occidentale 11-17 aprile 1985 (Spoleto, 1987), pp. 405-33.

${ }^{52}$ Chronicon de Lanercost, pp. 175-6.

${ }^{53}$ Cf. for example the 'Excommunication formula, about 900' and "'Pope Leo" excommunication formula, 937' in appendix C of Little, Benedictine Maledictions, pp. 255-8, with the Latin rite contained in a late $13^{\text {th }}$ or early $14^{\text {th }}$ century MS: British Library Additional 15236, f. 25r, and with the Middle English form in Leo Carruthers 'The Great Curse: Excommunication, canon law and the judicial system in late medieval society, through the eyes of an English preacher', Anglophonia, 29 (2011), 45-59. G. Steele Edwards, 'Ritual Excommunication in Medieval France and England, 900-1200', (Stanford University PhD thesis, 1997) also contains appendices with numerous formulae demonstrating the prevalence of such phrases. The British Library MS formula is just over 150 words. It begins by invoking various authorities (the Trinity, the Virgin Mary, angels, etc.), goes on to excommunicate and anathematize the malefactors, before cursing them while sitting, standing, eating, drinking, and so forth, declaring their affinity with Dathan and Abiron, Ananias and Sapphira, et al., then ends the ceremony by extinguishing candles representing their souls, as quoted above. A form of absolution follows in the manuscript.

${ }^{54}$ The Rolls and Register of Bishop Oliver Sutton, iv, pp. 117-18.

${ }^{55}$ Le Pontifical romain au moyen-âge, III: Le Pontifical de Guillaume Durand, ed. Michel Andrieu, Studi e Testi, 88 (Vatican City, 1940), pp. 609-15. 
part - but for particularly serious cases the full anathema, making use of Old Testament maledictions from the Psalms and Deuteronomy, could be used. Even if we err on the side of caution and conclude through lack of definite evidence that the more severe maledictions were not in use in thirteenth-century England, the final condemnation with candles was in any case the most explicit indication of what would happen to an excommunicate's soul. The ritual was unequivocal about the fate of an excommunicate. Yet it is crucial to note that this was only if he or she did not make amends and seek absolution. Excommunication was never supposed to be a permanent state, and however much it resembled a curse, this was always made clear. ${ }^{56}$ If an excommunicate died while sentenced, his or her irreparable exclusion from Christian society was demonstrated by burial outside consecrated ground.

The excommunication ceremony was supposed to be memorable and striking. People had to pay attention, either so that they knew who they were to shun, and why, or so that they were aware of sentences they would incur automatically. It is also clear that such ceremonies were supposed to be, and could be, terrifying. Robert Grosseteste, bishop of Lincoln (1235-53) described excommunications pronounced by Stephen Langton in 1222 'to terrify the wicked and restrain their wickedness' ${ }^{57}$ Robert Winchelsey, archbishop of Canterbury (1294-1313), explained that excommunication had to be pronounced 'with bells ringing and candles burning, so that it might be feared the more on account of this solemnity'. ${ }^{58}$ The solemnity was supposed to instil fear. And so it might. It is not hard to believe that the excommunication pronounced by Gregory IX against Emperor Frederick II in 1239 was terrifying, given the personal animosity the pope felt against the emperor. Matthew Paris reported that, 'in a spirit of fervent anger, [the pope] solemnly excommunicated the emperor Frederick ... handing him over to be terribly possessed, in destruction [of the flesh]. And using the same words, as if thundering in a roar of

\footnotetext{
${ }^{56}$ Jaser, 'Ritual excommunication: an "Ars Oblivionalis"?'

${ }^{57}$ Councils and Synods II, i, p. 275.

${ }^{58}$ Councils and Synods II, ii, p. 1194.
} 
fury, vehemently compelled all those listening to terror'. ${ }^{59}$ Paris presents the pope's use of the Corinthians verse as though he desired the emperor's affliction, and his passionate pronouncement apparently had a strong effect on his audience. Gregory used the same words in his letter to his legate in England, Otto, ordering him to publish the sentence: 'we resolved to promulgate a sentence of excommunication and anathema on him, handing over the same Frederick to Satan, in destruction of the flesh, so that on the Day of the Lord his spirit may be saved' ${ }^{60}$

For many, perhaps the majority, of excommunicates, the experience may have been relatively simple and bureaucratic. Yet it is certain that not all were, and that there remained plenty of opportunity for clerics to issue excommunications intended to scare sinners, perhaps intended to curse them and to send them to hell. In practice, there was room for a great deal of variety, and legal sources should not be allowed completely to overwhelm other source material. Moreover, in legislation and in miracles, excommunication continued to be presented as a bar to salvation, and a sentence to hell, certainly if the excommunicate remained contumacious. Such sources were far more likely to reach the majority of both clergy and laity than legalistic and theological explanations of excommunication. Chronicles are perhaps not always indicative of popular preconceptions, yet it is not surprising that, in the chronicle narratives, when bad things happened to excommunicates they were believed to result from sentences of excommunication. The fate of William Marshal's sons is one example of this. Another might be the belief that Louis's loss at the battle of Lincoln was because of his excommunicate status. ${ }^{61}$ If people did believe that excommunication resulted in damnation, and feared bad luck or death as a result of sentences, it should come as no surprise. They were repeatedly told, in a number of ways, that such things were possible. Excommunication was far less effective if it was not feared, and the

\footnotetext{
${ }^{59}$ Chronica Majora, iii, 533.

${ }^{60}$ Chronica Majora, iii, 571-2.

${ }^{61}$ Chronica de Mailros, ed. J. Stevenson, Bannatyne Club (Edinburgh, 1835), pp. 130-2; Fratri Walteri de Coventria, ed. W. Stubbs, RS (2 vols., 1872-3), ii, p. 239.
} 
church understandably sought to engineer such fear by retaining excommunication's links to cursing. 